Archived version from NCDOCKS Institutional Repository http://libres.uncg.edu/ir/asu/

\title{
Appalachỉan
}

B O O N E, N O R T H C A R O L I N A

\section{Six Principles For Remaining Positive In A Negative Work Environment}

\author{
By: Linda S. Johanson
}

\begin{abstract}
Nurses employed in a caustic work environment can find their ability to give quality patient care impeded. Situations in which there is incivility, high stress, jealousy, or harassment, exemplify work environments that can be discouraging, especially for Christian nurses who may have pursued the profession in response to a spiritual calling. There are biblical passages that nurses may use to help them cope, including six focus points to guide and encourage nurses in caustic work situations.
\end{abstract}

Johanson, Linda S. (2019). Six Principles For Remaining Positive In A Negative Work Environment. Journal of Christian Nursing, April/June 2019. Vol. 36, no. 2 - p E21- E24. doi: 10.1097/CNJ.0000000000000598. Publisher version of record available at: https://journals.lww.com/journalofchristiannursing/ Fulltext/2019/04000/Six_Principles_for_Remaining_Positive_in_a.23.aspx 


\section{Six Principles for Remaining Positive in a Negative Work Environment}

\begin{abstract}
Nurses employed in a caustic work environment can find their ability to give quality patient care impeded. Situations in which there is incivility, high stress, jealousy, or harassment, exemplify work environments that can be discouraging, especially for Christian nurses who may have pursued the profession in response to a spiritual calling. There are biblical passages that nurses may use to help them cope, including six focus points to guide and encourage nurses in caustic work situations.
\end{abstract}

KEY WORDS: caustic work environment, Christian, incivility, nursing, spiritual calling

A former nursing student recently emailed me, requesting a reference letter for a bachelor's degree program in elementary education. After only two years in what she considered a toxic work environment, with dissatisfied and angry nurse colleagues, she decided to abandon the profession in favor of a teaching career. This situation saddened me.

Virtually all nursing students I have taught have stated they chose the profession due to altruistic motives of caring for others. In my experience, Christian students especially have this perspective. After completing the challenge of a difficult and rigorous curriculum, they have enthusiastic expectations of helping others in their daily work. They look for jobs where

Linda Johanson, EdD, RN, is an associate professor in the Nursing Department at Appalachian State University in Boone, North Carolin She has been a nurse educator since 1980 , and she is a regular volunteer for medical mission work. they can best employ their caring talents.

\section{DREAM OR NIGHTMARE?}

So, what happens if nurses begin employment and find that a caustic work environment impedes this long-anticipated dream? They may have unknowingly joined a staff that is experiencing overwork stress or burnout. They may have a jealous preceptor, or may be exposed to workplace incivility, hostility, or even harassment. Those previous altruistic perceptions of nursing may begin to fade, and the threat of emotional distress and discouragement can result. Prevalence rates for incivility in workplaces are high; it has been correlated with stress, burnout, decreased psychological well-being, and decreased employee satisfaction and performance (Williams, 2017). It is easy for nurses to become overwhelmed and distracted by negative work environments. Yet, researchers have noted that positive organizational cultures seem to reduce workplace incivility (Laschinger, Wong, Cummings, \& Grau, 2014).
Evans (2017) asserts that preparation for coping in a potentially negative workplace should begin in nursing programs; however, in a concept-laden curriculum there tends to be little extra time. Recently I spoke with a graduate about her perceptions of her one-year nursing position at a major medical center. I was heartbroken to hear the sad lament from this previous honors-level nursing student. She stated that although giving patient care was satisfying, her co-workers just did not seem to care. She said they complained endlessly, talked rudely

about patients and other staff, and seemed to regard nursing as just a job for a paycheck. Abdollahzadeh, Asghari, Doshmangiri, Hasankhani, and Vahidi (2017) found that co-workers' carelessness, as well as new nurses' feelings of invisibility, and lack of environmental safety, may constitute incivility that can contribute to a caustic environment.

Even seasoned nurses can find themselves working in environments that are not conducive to the profession's 
caring ideals. I have heard nurses complain that the profession has changed, and that the job expectations are too great with too few resources. This situation may be especially distressing for Christian nurses, who may have pursued nursing because of a spiritual calling.

It is helpful to go back to spiritual roots when dealing with a caustic or negative work environment. Research suggests that more civil environments in nursing may result when spirituality is infused into the workplace (Phillips, MacKusick, \& Whichello, 2018). Before abandoning the profession or allowing a bad situation to fester, nurses can use biblical passages to help them in coping with negative work environments. The following six focus points of Scripture may guide and encourage nurses in caustic work situations.

\section{SIX FOCUS POINTS 1. Pray for your enemies.}

But I say to you who hear, Love your enemies, do good to those who hate you, bless those who curse you, pray for those who abuse you (Luke 6:27-28, NIV).

When one feels wronged, often a natural inclination is to wish ill on those causing the pain or discomfort. However, Jesus taught his followers to love. This is not easy, but it does take the focus off self and causes one to consider that life circumstances may be impacting the negative, arrogant, or jealous person that causes the behavior. The Holy Spirit can help us see the one contributing to a caustic work situation as a child of God in need of prayer and love.

I once worked for an administrator who rated those she liked favorably and those she did not like, negatively, regardless of their work profiles. This created animosity and jealousy among staff, as well as considerable stress.

Everyone was afraid to approach her for fear of landing on her dislike list. Several staff resigned; however, a small group of Christian staff chose to remain and make deliberate efforts to regularly pray for this supervisor. She did not change her behavior; however, praying for her did make those praying more tolerant as we kept focused on Christ.

\section{Exemplify Christian love in your behavior.}

Then they came to Jericho. As Jesus and his disciples, together with a large crowd, were leaving the city, a blind man, Bartimaeus (that is, the son of Timaeus), was sitting by the roadside begging. When he heard that it was Jesus of Nazareth, he began to shout, "Jesus, Son of David, have mercy on me!" Many rebuked him and told him to be quiet, but he shouted all the more, "Son of David, have mercy on me!" Jesus stopped and said, "Call him." So they called to the blind man, "Cheer up! On your feet! He's calling you." Throwing his cloak aside, he jumped to his feet and came to Jesus. "What do you want me to do for you?" Jesus asked him. The blind man said, "Rabbi, I want to see." "Go," said Jesus, "your faith has healed you." Immediately he received his sight and followed Jesus along the road (Mark 10:46-52, NIV).

Here,Jesus extended compassion by healing a blind man whose name meant son of unclean. It is likely the man was taunted as a dirty beggar. Not only was he physically cured, but likely saved from emotional distress. It would have been easy for Jesus to walk away from this distasteful situation and ignore the man's cries for help; however, he chose to exhibit compassion and care.

In a negative work situation, Christians are called to model similar character. When others are gossiping or complaining, it is not easy to avoid commenting. It can also be difficult to keep silent when a bully hurls insults. However, by aligning with the mind of Christ and his example, our resolve can strengthen.

Some time ago, I worked for a new supervisor who took over this position after I had been filling in on an interim basis. Because of this dynamic, our relationship was always tense. Whenever I offered an idea at a staff meeting, she consistently rejected it. Eventually, I was called to her office and admonished for bringing up ideas in what she considered an inappropriate manner. Rather than argue with her that a staff meeting is an appropriate avenue for ideas or noting that because the idea was different from hers did not make it inappropriate, I was able to remain calm and thank her for her perception. An argument was what she anticipated;

when one did not emerge, there was nothing to do except let it go.

We can overcome negative with good. Perhaps paying a compliment, word of encouragement, a smile, or a favor to one who is causing distress in the work environment, could change the climate. This verse is encouraging: "To the contrary: If your enemy is hungry, feed him; if he is thirsty, give him something to drink. In doing this, you will heap burning coals on his head. Do not be overcome by evil, but overcome evil with good" (Romans 12:20-21, NIV). 


\section{Entrust justice to God.}

If possible, so far as it depends on you, live peaceably with all. Beloved, never avenge yourselves, but leave it to the wrath of God, for it is written, "Vengeance is mine, I will repay, says the Lord" (Romans 12:18-19, ESV).

This verse has been a comfort in caustic work situations. Our natural inclination is to defend against perceived injustice. However, God asks us to entrust justice to him. Although we may want to take care of things on our own, God is the only one who can judge with righteousness. Jesus stated, "But I tell you, do not resist an evil person. If anyone slaps you on the right cheek, turn to them the other cheek also" (Matthew 5:39, NIV). In Ephesians 6:12-13, we are reminded that spiritual forces are at work against us. Paul states that we have the full armor of God available, such that we may stand our ground.

I am reminded of when faculty co-workers regarded a former department chairperson as someone noted for placing most of her responsibilities on subordinates. She seemed to enjoy her administrative position mostly for its fame and notoriety but put little work into the accompanying responsibilities. Instead, she took credit for the work of others. Some faculty members decided to write an anonymous letter to her superior, hoping to have her dismissed. A comprehensive list of complaints, with exemplars, was included.

Of course, the hoped-for dismissal never emerged. If anything, new futility fueled the discontent, and this supervisor remained in her position with unchanged behavior. Planning retaliation is not a successful strategy, and we should never feel it is our place to get even. Instead, we need to trust God to make things right. We may be comforted by the following verses:
The righteous man may have many troubles, but the Lord delivers him from them all (Psalm 34:19, NIV). Though I walk in the midst of trouble, you preserve my life; you stretch out your hand against the anger of my foes, with your right hand you save me (Psalm 138:7, NIV).

\section{Draw strength from adversity.}

Consider it pure joy, my brothers, whenever you face trials of many kinds, because you know that the testing of your faith produces perseverance. Perseverance must finish its work so that you may be mature and complete, not lacking anything (James 1:2-4, NIV).

Here we are encouraged to be glad for trials, as they test our faith and produce perseverance, which helps us to mature in Christ. Instead of being discouraged, upset, and bitter about a work situation, we have the capacity to change our perspective. We can consider what God might be teaching us through this trial. We need to pray for direction to sense how difficult work situations can grow us spiritually.

We have all worked with people who, for some reason, do not like us. I recall a colleague who had worked many years at the workplace I had recently joined. I had many years of nursing experience and multiple degrees, so I believe she might have felt threatened by me. It was disturbing to the entire faculty group because she would approach others to gossip about me, making them uncomfortable. My inclination was to resign and not have to deal with it. However, God was able to help me see that my goal is not to acquire the accolades of men, but rather to care about God's perception of me. Up to that point, I had tended to be a people-pleaser, and I could not stand for others to dislike me. Through prayer, God was able to show me there will always be people who do not like me, and it is futile to try to please all. If God is pleased with my behavior, that is sufficient. The adverse work climate encouraged me to approach God for this discernment.

\section{Consider becoming a change agent.}

\author{
Blessed are the peacemakers, for \\ they shall be called sons of God \\ (Matthew 5:9, ESV).
}

If you are being mistreated at work, or if you see a problematic situation has emerged, biblical wisdom encourages us to be a part of making an environmental change. It may not always be in your control; however, you might help with a creative solution.

With assessment for a root cause, you may be able to determine what makes the work environment toxic and discern whether you are to implement change. Perhaps the unit is understaffed, leading to stress. You might join a committee to work on staffing problems. Maybe someone feels threatened or insecure, so he or she acts out.Your positive encouragement may make a difference. Perhaps the staff suffers because everyone is so busy there is no time for bonding or getting to know one another.You might consider a creative contest or fundraising activity that brings a common focus to the unit.

In academic settings, I have seen the environment degrade because faculty go separate ways for clinical, class, and work on independent research. Without an 
effort to keep in touch, relationships can become distant, and misunderstandings occur. In our university setting, we decided to circumvent this by structuring quarterly faculty social events. At each semester's beginning, prior to the start of classes, and each semester's end, when faculty had greater flexibility, some type of gathering (always involving food) was held. This simple solution helped keep us connected.

\section{Examine your behavior for pos- sible contribution to a problem.}

When his brothers saw that their father loved him more than any of them, they hated him and could not speak a kind word to him (Genesis 37:4, NIV).

When I first became acquainted with the biblical account of Joseph, all I saw was the cruelty that Joseph endured at the hands of his brothers, who hated him because of his father's favoritism toward Joseph. The brothers eventually sold Joseph into slavery. More recently, I have considered that Joseph could have contributed to the unfavorable climate. Did he flaunt his father's preference toward him by wearing his special multicolored coat in front of them? When telling his brothers of his dream that they would bow down to him, was it conveyed with a superior attitude? I started considering the contribution we sometimes might make to negative environments, without it being our intention.

$\bar{P}$

When we moved to a southern state from the Midwest, after sharing what I thought was a great idea in my new workplace, I was told that everything I shared was prefaced with, "Where I used to work, we did...." I had attributed my perception of a somewhat cold reception from this group as related to North versus South cultural distinctions. Although that may have been a factor, I concluded that my new colleagues had probably perceived me as acting superior because of my past experiences. Removing that phrasing and listening first eventually resulted in warming my reception and creating lasting friendships.

\section{CONCLUSION}

For many reasons, nurses may find themselves in negative work environments that impede their ability to provide a caring focus toward patient care. When this occurs, it is possible to draw strength from biblical references that provide guidance and encouragement. The six focus points outlined in this article have been a great help in the academic, workplace, and mission settings where this author practices. Readers may find them helpful, too. $D$

Abdollahzadeh, F., Asghari, E., Doshmangiri, L., Hasankhani, H., \& Vahidi, M. (2017). Incivility as an extensively used, but seldom defined concept in nursing. Nursing \& Midwifery Studies, 6(2), 1-4. doi:10.5812/ nmsjournal.41029

Evans, G. (2017). Training for toxic work culture should start in nursing school, preparing for incivility, bullying, preventing violence. Hospital Employee Health, 36(5), 49-60.

Laschinger, H. K., Wong, C. A., Cummings, G. G., \& Grau, A. L. (2014). Resonant leadership and workplace empowerment: The value of positive organizational cultures in reducing workplace incivility. Nursing Economic\$, 32(1), 5-15.

Phillips, G. S., MacKusick, C. I., \& Whichello, R. (2018). Workplace incivility in nursing: A literature review through the lens of ethics and spirituality. Journal of Christian Nursing, 35(1), E7-E12. doi:10.1097/ CNJ.0000000000000467

Williams, R. (2017). The rise of incivility in America. Retrieved from https://raywilliams.ca/the-rise-ofincivility-in-america/ 